\title{
Effects of SM-9018, a Potential Atypical Neuroleptic, on the Central Monoaminergic System in Rats
}

\author{
Yoshimi Maruoka, Yukihiro Ohno*, Terufumi Kato, Akira Hirose, Tohru Tatsuno and Mitsutaka Nakamura \\ Research Laboratories, Sumitomo Pharmaceuticals Co., Ltd., 3-1-98 Kasugadenaka, Konohana-ku, Osaka 554, Japan \\ Received April 13, 1993 Accepted June 17, 1993
}

\begin{abstract}
The effects of SM-9018, a potential atypical neuroleptic, on monoamine metabolism were studied in rats. SM-9018 dose-dependently increased the levels of 3,4-dihydroxyphenylacetic acid (DOPAC) and homovanillic acid (HVA) in the cerebral cortex and striatum without affecting the levels of 5-HT, norepinephrine and their metabolites. This action persisted for $8 \mathrm{hr}$ with a maximum effect at $1-2 \mathrm{hr}$. The SM-9018-induced increase of dopamine (DA) turnover, as indexed by HVA/DA and DOPAC/DA ratios, was comparable in the cerebral cortex and striatum, whereas the typical neuroleptic haloperidol preferentially enhanced the striatal DA turnover. These findings suggest that SM-9018, unlike haloperidol, increases DA turnover to a similar extent both in the cerebral cortex and striatum.
\end{abstract}

Keywords: SM-9018, Neuroleptic, Monoamine

It is well documented that dopamine (DA) $\mathrm{D}_{2}$ blocking activities of neuroleptics correlate well with their clinical efficacy against schizophrenia (1). However, most neuroleptics are only effective for the positive symptoms of schizophrenia (e.g., hallucination and delusion), but not for the negative symptoms (e.g., apathy, social withdrawal and flattening affection) (2). In addition, they often produce severe extrapyramidal side-effects (EPS) such as akathisia, parkinsonism and tardive dyskinesia during the treatment. Recent clinical studies $(3-5)$ have shown that the blockade of central $5-\mathrm{HT}_{2}$ receptors provides beneficial effects in the treatment of schizophrenia, such as 1) amelioration of the negative symptoms, 2) reduction of EPS associated with typical neuroleptic treatment and 3) improvement of sleep quality.

SM-9018 (cis-2-(4-(4-(1,2-benzoisothiazol-3-yl)-1-piperazinyl)butyl)hexahydro- $1 H$-isoindole-1,3(2H)-dione $\mathrm{HCl}$ ) is a novel neuroleptic candidate that has combined $5-\mathrm{HT}_{2}$ and $\mathrm{D}_{2}$ blocking actions. The compound exhibits high affinities for both 5- $\mathrm{HT}_{2}$ and $\mathrm{D}_{2}$ receptors $\left(\mathrm{K}_{\mathrm{i}}\right.$ value $=0.61$ and $1.4 \mathrm{nM}$, respectively) and potently blocks various behaviors mediated by these receptors $(6,7)$. In addition, SM-9018 is much weaker than the typical neuroleptics, haloperidol and chlorpromazine, in inducing catalepsy in rodents (6). Therefore, SM-9018 seems likely to be one

\footnotetext{
* To whom all correspondence should be addressed.
}

of the so-called atypical neuroleptics (e.g., clozapine, thioridazine and sulpiride), which are characterized by a low incidence of EPS in humans. In the present study, we studied the effects of SM-9018 on monoamine metabolism in rats using ex vivo measurement methods and compared its effects to those of haloperidol.

Male Sprague-Dawley rats (Japan SLC, Inc., Shizuoka), each weighing $200-230 \mathrm{~g}$, were used. On the day of the experiments, the animals were killed by decapitation after oral administration of drugs or vehicle (control). The brain was rapidly removed, chilled in ice-cold saline and dissected into eight brain regions: cerebral cortex, striatum, hippocampus, thalamus, hypothalamus, mesencephalon, pons-medulla oblongata and cerebellum. The rostroventral part of the striatum (approximately a 2-mm block) containing the nucleus accumbens was removed to reduce its influence on striatal monoamine metabolism. The tissues were then frozen in ethanol-dry ice and stored at $-70^{\circ} \mathrm{C}$ until the analysis.

Monoamines and their metabolites were analyzed using high performance liquid chromatography with electrochemical detection (HPLC-ECD), as described previously (8). Briefly, the brain tissues were homogenized in 5-9 volumes of ice-cold $0.1 \mathrm{~N}$ perchloric acid containing 5 mM EDTA $2 \mathrm{Na}$ and isoproterenol (internal standard). After centrifugation at $10,000 \times \mathrm{g}$ for $30 \mathrm{~min}$ at $4^{\circ} \mathrm{C}$, aliquots of the supernatant were applied to the HPLC-ECD 
system. For determination of the total 3-methyl-4-hydroxyphenylethyleneglycol (MOPEG) level, a sulfate conjugated form of MOPEG (MOPEG-SO ${ }_{4}$ ) was hydrolyzed with sulfatase, and then applied to the HPLC-ECD system.

SM-9018 and haloperidol were synthesized at Sumitomo Pharmaceuticals Co., Ltd. Other drugs used in this study were as follows: 3,4-dihydroxyphenylacetic acid (DOPAC), 5-hydroxyindoleacetic acid (5-HIAA), MOPEG piperazine salt and sodium octylsulphate (Aldrich Chem., Milwaukee, WI, U.S.A.); 5-HT creatinine sulfate, DL-isoproterenol $\mathrm{HCl}$ and DL-norepinephrine (NE) $\mathrm{HCl}$ (Nacalai Tesque, Kyoto); homovanillic acid (HVA) and sulfatase (H-1 type) (Sigma Chem., St. Louis, MO, U.S.A.); and DA HCl (Wako Pure Chem., Osaka). SM-9018 and haloperidol were suspended in $0.5 \%$ methylcellulose solution and orally administered at a volume of $5 \mathrm{ml} / \mathrm{kg}$ body weight. Control animals were given an equivalent volume of vehicle alone.

Student's $t$-test was used only for comparisons between the two groups. Statistical significance in the DA turnover ratios between the cortex and striatum was determined by two-way ANOVA followed by Williams' multiple comparison test.

The levels of DA, 5-HT, NE and their metabolites in the various brain regions were measured $1 \mathrm{hr}$ after oral administration of SM- 9018 at $10 \mathrm{mg} / \mathrm{kg}$. This dose of SM9018 was sufficient to block both $5-\mathrm{HT}_{2}$ and $\mathrm{D}_{2}$ receptors in various behavioral tests (6). As shown in Table 1, SM9018 significantly $(\mathrm{P}<0.01)$ increased the level of DA metabolites, DOPAC and HVA, in the cerebral cortex and striatum, but not in other brain regions, i.e., hip- pocampus, hypothalamus, thalamus, mesencephalon, pons-medulla oblongata and cerebellum. DOPAC and HVA contents in the cerebral cortex and striatum increased 2- to 2.5-fold in rats treated with SM-9018 as compared to those in control rats. Slight (but not significant) increases in DOPAC and HVA levels were also observed in the hypothalamus, thalamus and mesencephalon. No significant change in DA level was found in any brain region examined. In addition, SM-9018 did not significantly change the level of 5-HT, NE or their metabolites (i.e., 5-HIAA and MOPEG, respectively) in any brain region examined.

Figure 1 shows the time-course of the effects of SM9018 on DA turnover, as indexed by HVA/DA and DOPAC/DA ratios. SM- 9018 at $10 \mathrm{mg} / \mathrm{kg}$ (p.o.) rapidly increased the DA turnover in the cerebral cortex and striatum. The HVA/DA and DOPAC/DA ratios in both brain regions reached to about 400 and $250-300 \%$ of the control level, respectively, within $1-2 \mathrm{hr}$, and these effects persisted up to $8 \mathrm{hr}$.

We next compared the effects of SM-9018 on DA turnover with those of a typical neuroleptic haloperidol. As shown in Fig. 2, orally administered SM-9018 at 0.3-30 $\mathrm{mg} / \mathrm{kg}$ dose-dependently increased HVA/DA and DOPAC/DA ratios in the cerebral cortex and striatum. The dose-response curves for the increase of HVA/DA and DOPAC/DA ratios by SM-9018 were practically comparable in the two areas, and the ratios were about $400 \%$ and $350 \%$ of the control level, respectively, at $30 \mathrm{mg} / \mathrm{kg}$ (Fig. 2A). Haloperidol at $0.1-10 \mathrm{mg} / \mathrm{kg}$ (p.o.) also increased the HVA/DA and DOPAC/DA ratio in a dose-

Table 1. Effects of SM-9018 on norepinephrine (NE), dopamine (DA), 5-HT and their metabolite levels in various regions of the rat brain

\begin{tabular}{|c|c|c|c|c|c|c|c|c|c|c|c|}
\hline \multirow{2}{*}{ Brain regions } & & \multicolumn{3}{|c|}{ Monoamines (ng/g tissue) } & \multicolumn{7}{|c|}{ Metabolites (ng/g tissue) } \\
\hline & & \multirow{2}{*}{$\begin{array}{cr}\text { NE } \\
270 \pm 13 \\
244 \pm 5\end{array}$} & \multirow{2}{*}{$\begin{array}{c}\text { DA } \\
220 \pm 39 \\
203 \pm 32\end{array}$} & \multirow{2}{*}{$\begin{array}{c}5-\mathrm{HT} \\
304 \pm 15 \\
300 \pm 9\end{array}$} & \multicolumn{2}{|c|}{ MOPEG } & \multicolumn{2}{|c|}{ DOPAC } & \multicolumn{2}{|c|}{ HVA } & 5-HIAA \\
\hline $\begin{array}{l}\text { Cerebral } \\
\text { cortex }\end{array}$ & $\begin{array}{l}\text { Control } \\
\text { SM-9018 }\end{array}$ & & & & $\begin{array}{l}38 \pm \\
42 \pm\end{array}$ & $\begin{array}{l}2 \\
3\end{array}$ & $\begin{array}{r}48 \pm \\
100 \pm\end{array}$ & $\begin{array}{c}6 \\
14^{*}\end{array}$ & $\begin{array}{r}49 \pm \\
106 \pm\end{array}$ & $11^{3}$ & $\begin{array}{ll}183 \pm & 5 \\
171 \pm & 8\end{array}$ \\
\hline Striatum & $\begin{array}{l}\text { Control } \\
\text { SM-9018 }\end{array}$ & $\begin{array}{r}106 \pm \quad 7 \\
97 \pm \quad 4\end{array}$ & $\begin{array}{l}7573 \pm 279 \\
6738 \pm 388\end{array}$ & $\begin{array}{l}464 \pm 19 \\
424 \pm 23\end{array}$ & $\begin{array}{l}61 \pm \\
62 \pm\end{array}$ & $\begin{array}{l}7 \\
3\end{array}$ & $\begin{array}{l}1305 \pm \\
2930 \pm 3\end{array}$ & $\begin{array}{l}65 \\
683^{*}\end{array}$ & $\begin{array}{c}712 \pm \\
1798 \pm 1\end{array}$ & $\begin{array}{c}29 \\
188^{*}\end{array}$ & $\begin{array}{l}482 \pm 19 \\
483 \pm 14\end{array}$ \\
\hline Hippocampus & $\begin{array}{l}\text { Control } \\
\text { SM-9018 }\end{array}$ & $\begin{array}{ll}325 \pm & 11 \\
307 \pm & 16\end{array}$ & $\begin{array}{l}13 \pm 2 \\
16 \pm 5\end{array}$ & $\begin{array}{l}337 \pm 8 \\
316 \pm 29\end{array}$ & $\begin{array}{l}39 \pm \\
42 \pm\end{array}$ & $\begin{array}{l}4 \\
2\end{array}$ & $\begin{array}{l}6 \pm \\
7 \pm\end{array}$ & $\begin{array}{l}1 \\
1\end{array}$ & $\begin{array}{l}10 \pm \\
11 \pm\end{array}$ & $\begin{array}{l}2 \\
2\end{array}$ & $\begin{array}{l}284 \pm 6 \\
278 \pm 17\end{array}$ \\
\hline Hypothalamus & $\begin{array}{l}\text { Control } \\
\text { SM-9018 }\end{array}$ & $\begin{array}{l}1120 \pm 139 \\
1038 \pm 86\end{array}$ & $\begin{array}{l}382 \pm 29 \\
334 \pm 31\end{array}$ & $\begin{array}{l}579 \pm 24 \\
630 \pm 35\end{array}$ & $\begin{array}{l}70 \pm \\
66 \pm\end{array}$ & $\begin{array}{l}6 \\
4\end{array}$ & $\begin{array}{l}79 \pm \\
94 \pm\end{array}$ & $\begin{array}{l}6 \\
7\end{array}$ & $\begin{array}{l}48 \pm \\
53 \pm\end{array}$ & $\begin{array}{l}5 \\
5\end{array}$ & $\begin{array}{l}535 \pm 27 \\
476 \pm 22\end{array}$ \\
\hline Thalamus & $\begin{array}{l}\text { Control } \\
\text { SM-9018 }\end{array}$ & $\begin{array}{l}428 \pm 30 \\
404 \pm 18\end{array}$ & $\begin{array}{ll}41 \pm & 2 \\
38 \pm & 2\end{array}$ & $\begin{array}{l}430 \pm 39 \\
408 \pm 20\end{array}$ & $\begin{array}{l}80 \pm \\
86 \pm\end{array}$ & $\begin{array}{l}7 \\
6\end{array}$ & $\begin{array}{l}13 \pm \\
17 \pm\end{array}$ & $\begin{array}{l}1 \\
2\end{array}$ & $\begin{array}{l}17 \pm \\
25 \pm\end{array}$ & $\begin{array}{l}2 \\
4\end{array}$ & $\begin{array}{l}518 \pm 26 \\
461 \pm 34\end{array}$ \\
\hline Mesecephalon & $\begin{array}{l}\text { Control } \\
\text { SM-9018 }\end{array}$ & $\begin{array}{l}549 \pm 28 \\
541 \pm 5\end{array}$ & $\begin{array}{l}135 \pm 20 \\
158 \pm 16\end{array}$ & $\begin{array}{l}739 \pm 24 \\
703 \pm 37\end{array}$ & $\begin{array}{l}70 \pm \\
76 \pm\end{array}$ & $\begin{array}{l}4 \\
5\end{array}$ & $\begin{array}{l}34 \pm \\
49 \pm\end{array}$ & $\begin{array}{l}5 \\
6\end{array}$ & $\begin{array}{l}48 \pm \\
57 \pm\end{array}$ & $\begin{array}{l}4 \\
3\end{array}$ & $\begin{array}{l}589 \pm 24 \\
577 \pm 29\end{array}$ \\
\hline $\begin{array}{l}\text { Pons-medulla } \\
\text { oblongata }\end{array}$ & $\begin{array}{l}\text { Control } \\
\text { SM-9018 }\end{array}$ & $\begin{array}{l}579 \pm 10 \\
581 \pm 6\end{array}$ & $\begin{array}{ll}50 \pm & 3 \\
50 \pm & 2\end{array}$ & $\begin{array}{l}530 \pm 14 \\
531 \pm 15\end{array}$ & $\begin{array}{l}74 \pm \\
85 \pm\end{array}$ & $\begin{array}{l}7 \\
6\end{array}$ & $\begin{array}{l}22 \pm \\
23 \pm\end{array}$ & $\begin{array}{l}1 \\
1\end{array}$ & $\begin{array}{l}32 \pm \\
33 \pm\end{array}$ & $\begin{array}{l}2 \\
2\end{array}$ & $\begin{array}{l}354 \pm 14 \\
348 \pm 21\end{array}$ \\
\hline Cerebellum & $\begin{array}{l}\text { Control } \\
\text { SM-9018 }\end{array}$ & $\begin{array}{l}316 \pm 16 \\
285 \pm 15\end{array}$ & $\begin{array}{ll}13 \pm & 1 \\
12 \pm & 1\end{array}$ & $\begin{array}{ll}58 \pm & 3 \\
51 \pm & 2\end{array}$ & $\begin{array}{l}43 \pm \\
44 \pm\end{array}$ & $\begin{array}{l}2 \\
4\end{array}$ & $\begin{array}{l}4 \pm \\
5 \pm\end{array}$ & $\begin{array}{l}0 \\
0\end{array}$ & $\begin{array}{l}10 \pm \\
10 \pm\end{array}$ & $\begin{array}{l}1 \\
0\end{array}$ & $\begin{array}{ll}44 \pm & 3 \\
41 \pm & 3\end{array}$ \\
\hline
\end{tabular}

SM-9018 at $10 \mathrm{mg} / \mathrm{kg}$ or vehicle (control) was orally administered $1 \mathrm{hr}$ before decapitation. Each value represents the mean \pm S.E.M. of 6 animals. ${ }^{*} \mathrm{P}<\mathbf{0 . 0 1}$, Significantly different from the control group (Student's $t$-test). 

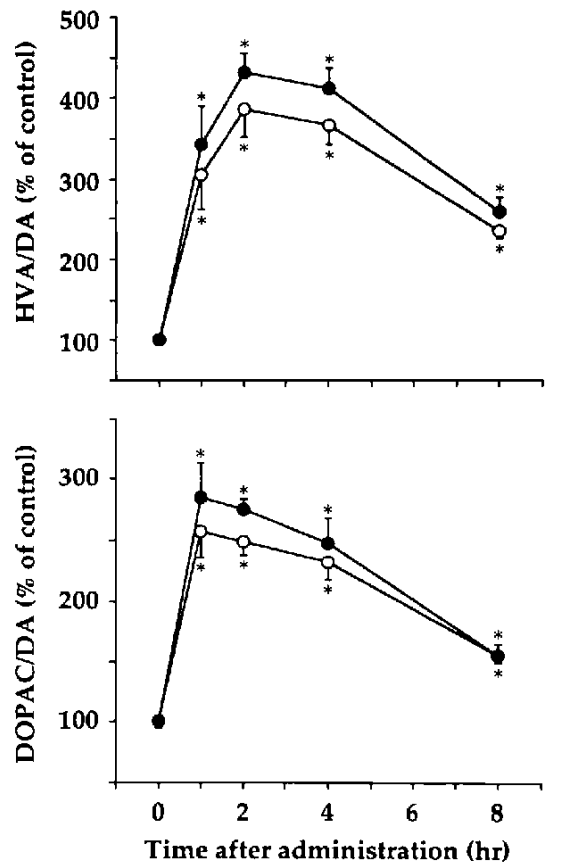

Fig. 1. Time course of the effects of SM-9018 on dopamine turnover in the rat cerebral cortex and striatum. SM-9018 at $10 \mathrm{mg} / \mathrm{kg}$ was orally administered $1-8 \mathrm{hr}$ before decapitation. Each point represents the mean \pm S.E.M. of 5 or 6 animals. ${ }^{*} \mathrm{P}<0.01$, Significantly different from the control value (one-way ANOVA and Williams' test). Striatum, $\bigcirc$ Cortex.

dependent manner (Fig. 2B). However, the extent of haloperidol-induced DA turnover in the striatum was significantly higher (by two-way ANOVA) than that in the cerebral cortex. Thus haloperidol at $3-10 \mathrm{mg} / \mathrm{kg}$ produced significantly greater increases in HVA/DA and DOPAC/DA ratios in the striatum (ca. $300-350 \%$ of the control) than in the cerebral cortex (ca. $250 \%$ of the control) (Fig. 2B).

Neuroleptics are known to increase the DA metabolite level and enhance DA turnover in the striatum and cerebral cortex, which are innervated by DA neurons derived from the substantia nigra and ventral tegmental area, respectively (1). This increase in DA turnover has been considered to be compensatory for the antagonism of the $D_{2}$ receptor by neuroleptics. The blockade of $D_{2}$ autoreceptors on the nerve terminals and soma/dendritic portions of DA neurons reportedly enhances the synthesis and synaptic release of DA and increases the firing of DA neurons (9). In addition, the blockade of postsynaptic $\mathrm{D}_{2}$ receptors by neuroleptics has also been shown to increase the firing of DA neurons through discharge of the GABAmediated negative feedback mechanism (9). In the present study, SM-9018 selectively increased the DOPAC and HVA levels in the cerebral cortex and striatum without significantly affecting those in the other brain regions. The

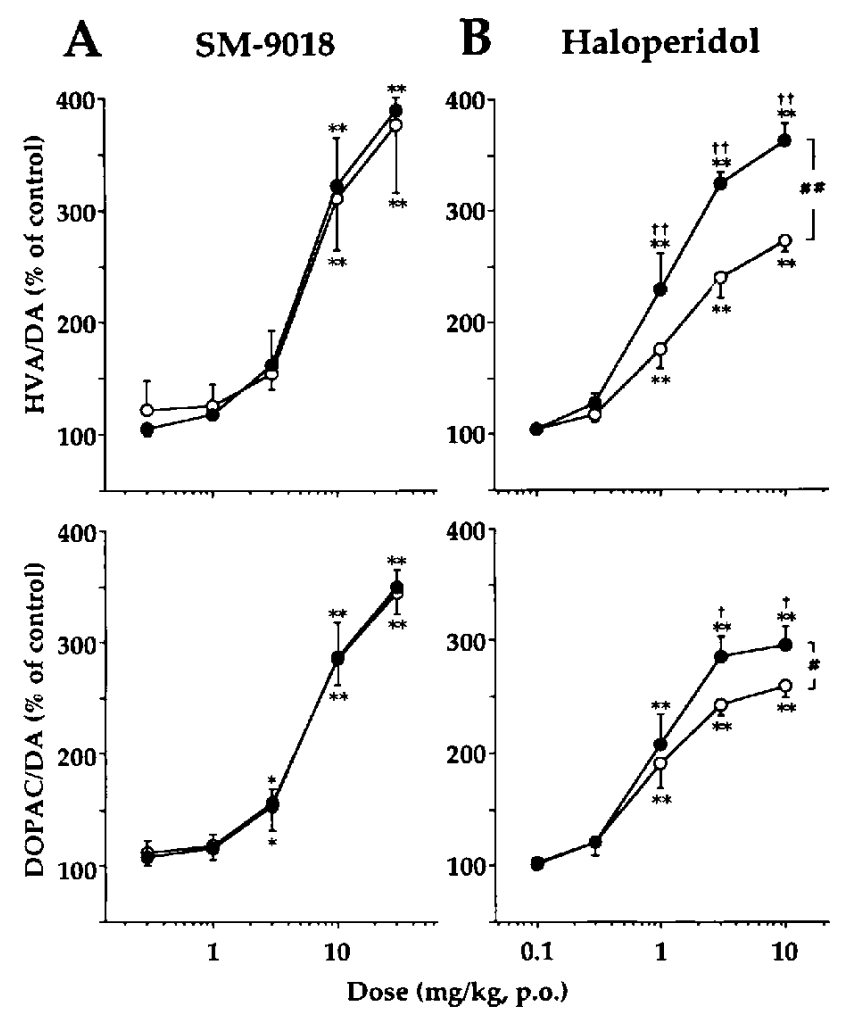

Fig. 2. Comparative effects of SM-9018 (A) and haloperidol (B) on dopamine turnover in rat cerebral cortex and striatum. SM-9018 at $0.3-30 \mathrm{mg} / \mathrm{kg}$ or haloperidol at $0.1-10 \mathrm{mg} / \mathrm{kg}$ was orally administered $1 \mathrm{hr}$ before decapitation. Each point represents the mean \pm S.E.M. of six animals. ${ }^{*} \mathrm{P}<0.05,{ }^{* *} \mathrm{P}<0.01$, Significantly different from the control value (two-way ANOVA and Williams' test). ${ }^{\dagger} \mathrm{P}<0.05,{ }^{++} \mathrm{P}<0.01$, Significantly different from the value in the cerebral cortex (two-way ANOVA and Williams' test). ${ }^{*} \mathrm{P}<0.05$, ${ }^{\text {". }} \mathrm{P}<0.01$, Significantly different between striatum and cerebral cortex (two-way ANOVA). Striatum, $\bigcirc$ Cortex.

levels of NE, 5-HT and their metabolites were not significantly changed by SM-9018 treatment. The time course and dose response of the action of SM-9018 were relatively consistent with its $D_{2}$ blocking activities in various behavioral tests (6), in that SM-9018 inhibited methamphetamine-induced hyperactivity, apomorphineinduced climbing behavior and stereotypy with $E_{50}$ values of 2.2 to $5.8 \mathrm{mg} / \mathrm{kg}$, p.o., thus suggesting that SM9018 increased the DA metabolite levels through its $\mathrm{D}_{2}$ blocking activity.

SM-9018 is a potent antagonist of $5-\mathrm{HT}_{2}$ receptors (6). In addition, SM-9018 binds to $5-\mathrm{HT}_{1 \mathrm{~A}}$ receptors with a relatively high affinity (7). However, in this study, SM9018 did not significantly change the levels of 5-HT or 5HIAA in any brain regions examined. Our findings are consistent with previous findings $(10,11)$ that selective 5$\mathrm{HT}_{2}$ antagonists (i.e., ritanserin and ICI-169,369) did not affect the 5-HT metabolism in the rat striatum, cortex and olfactory tubercle. In addition, SM-9018 may act as an an- 
tagonist rather than agonist for $5-\mathrm{HT}_{1 \mathrm{~A}}$ receptors since 5 $\mathrm{HT}_{\text {IA }}$ receptor agonists (e.g., 8-OH-DPAT, tandospirone), but not antagonists (e.g., pindolol), reportedly reduced the activity of 5-HT neurons and lowered the 5HIAA level $(5,8,12)$. This is in agreement with the fact that SM-9018 did not induce any $5-\mathrm{HT}_{1 \mathrm{~A}}$ receptor-related behaviors (e.g., fore-paw treading and flat body) as described previously (7). Our results, however, do not rule out a possibility that SM-9018 failed to interact with $5-\mathrm{HT}_{1 \mathrm{~A}}$ receptors under our experimental conditions.

SM-9018 was much weaker than haloperidol and chlorpromazine in inducing catalepsy in rodents (6). The $\mathrm{ED}_{50}$ values for catalepsy induction were about 20-50 times higher than those for $D_{2}$ receptor antagonism. This suggests that SM-9018 is an atypical neuroleptic characterized by the low incidence of EPS in humans. The $\mathrm{D}_{2}$ receptor blockade in the cerebral cortex and/or limbic structures by neuroleptics has been implicated in their antipsychotic activities, whereas their action in the striatum has been suggested to be related to EPS (5). In this study, SM-9018 increased the HVA/DA and DOPAC/DA ratios to a similar extent both in the cerebral cortex and striatum. The dose-response curves for the increase in DA turnover by SM-9018 were also comparable between the two brain structures. In contrast, the typical neuroleptic haloperidol produced greater increases in DA turnover in the striatum than in the cerebral cortex. These findings indicate that the action of SM-9018 in the striatum relative to that in the cerebral cortex is weaker than that of haloperidol. Our findings are consistent with previous reports $(13-15)$ indicating that atypical neuroleptics (e.g., clozapine) exhibit similar potencies in increasing DA turnover both in the cortex and striatum, whereas typical neuroleptics (e.g., haloperidol) preferentially enhance the striatal DA turnover. Thus SM-9018, like other atypical neuroleptics, appeared to have a propensity to act on the mesocortical (vs. nigrostriatal) dopaminergic system as compared with typical neuroleptics. This may in part account for the lower incidence of EPS with SM9018. Further studies are required to clarify the action mechanism of SM- 9018 .

\section{REFERENCES}

1 Seeman, P.: Dopamine receptors and the dopamine hypothesis of schizophrenia. Synapse 1, 133-152 (1987)
2 Davis, J.M., Janicak, P., Linden, R., Moloney, J. and Pavkovic, I.: Neuroleptics and psychiatric disorders. In Neuroleptics: Neurochemical, Behavioral and Clinical Perspectives, Editied by Coyle, J.J. and Enna, S.J., pp. 15-64, Raven Press, New York (1983)

3 Bersani, G., Grispini, A., Marini, S., Pasini, A., Valducci, M. and Ciani, N.: Neuroleptic-induced extrapyramidal side effects: clinical perspectives with ritanserin ( $R$ 55667), a new selective 5 $\mathrm{HT}_{2}$ receptor blocking agent. Curr. Ther. Res. 40, 492-500 (1986)

4 Reyntjens, A., Gelders, Y.G., Hoppenbrouwers, M.-L.J.A. and Vanden Bussche, G.: Thymosthenic effects of ritanserin ( $R$ 55667), a centrally acting serotonin- $S_{2}$ receptor blocker. Drug Dev. Res. 8, 205-211 (1986)

5 Meltzer, H.Y. and Nash, J.F.: Effects of antipsychotic drugs on serotonin receptors. Pharmacol. Rev. 43, 587-604 (1991)

6 Hirose, A., Kato, T., Ohno, Y., Shimizu, H., Tanaka, H., Nakamura, M. and Katsube, J.: Pharmacolgical actions of SM9018, a new neuroleptic drug with both potent 5-hydroxytryptamine $_{2}$ and dopamine $e_{2}$ antagonistic actions. Japan. J. Pharmacol. 53, 321-329 (1990)

7 Kato, T., Hirose, A., Ohno, Y., Shimizu, H., Tanaka, H. and Nakamura, M.: Binding profile of SM-9018, a novel antipsychotic candidate. Japan. J. Pharmacol. 54, 478-481 (1990)

8 Tatsuno, T., Shimizu, H., Hirose, A., Tanaka, H., Kumasaka, Y. and Nakamura, M.: Effects of the putative anxiolytic SM3997 on central monoaminergic systems. Pharmacol. Biochem. Behav. 32, 1049 - 1055 (1989)

9 Bannon, M.J. and Roth, R.H.: Pharmacology of mesocortical dopamine neurons. Pharmacol. Rev. 35, 53-68 (1983)

10 Leysen, J.E., Gommeren, W., Van Gompel, P., Wynants, J., Janssen, P.F.M. and Laduron, P.M.: Receptor-binding properties in vitro and in vivo of ritanserin. A very potent and long acting serotonin- $S_{2}$ antagonist. Mol. Pharmacol. 27, 600-611 (1985)

11 Saller, C.F., Czupryna, M.J. and Salama, A.I.: 5-HT receptor $^{2}$ blockade by ICI 169,369 and other 5-HT 2 antagonists modulates the effects of D-2 dopamine receptor blockade. J. Pharmacol. Exp. Ther. 253, 1162-1170 (1990)

12 Goodwin, G.M. and Green, A.R.: A behavioral and biochemical study in mice and rats of putative selective agonists and antagonists for 5- $\mathrm{HT}_{1}$ and 5- $\mathrm{HT}_{2}$ receptors. Br. J. Pharmacol. 84, $743-753$ (1985)

13 Eichenberger, E.: Pharmacology of fluperlapine compared with clozapine. Arzneimittelforschung 34, 110-113 (1984)

14 Burki, H.R.: Effects of fluperlapine on dopaminergic systems in rat brain. Psychopharmacology (Berlin) 89, 77-84 (1986)

15 Chang, W.H., Chen, T.Y. and Yeh, E.K.: Time-course curves of homovanillic acid in caudate and pre-frontal cortex following acute neuroleptic administration. Psychopharmacology (Berlin) 93, 403-404 (1987) 